DOI: 10.20472/BMC.2018.007.006

MARCO TALIENTO

University of Foggia, Department of Economics, Italy

\title{
ON THE QUEST FOR VALUE IN THE PUBLIC SECTOR MANAGEMENT AND ITS IMPLICATIONS
}

\begin{abstract}
:
This paper seeks to draw the attention to a peculiar, complex and interesting issue: the search for value in the public organizations' management. Thus, after a brief reference to the classical theme of creation and measurement of the general economic-financial value for (Business / Private) firms, it focuses on the more insidious and much less quantitative argument of the generation and management of Public value. Public value is the equivalent (though modified) of shareholder value (SHV) in public management with special features. A first model internationally diffused in public sector studies is representable by means of the Strategic Triangle; whose angles are: 1) Vision (value); 2) Legitimacy \& support; 3) Operational capability of the public organization. A second model concerns more directly the first, highest, angle (that is now zoomed and founded upon resources and competencies): the value created for citizens through public services above all as mission. The building blocks and the outcomes $\&$ metrics developments are the elements that constitute a PSV (Public Service Value) scheme. A comparative analysis per stages is essential for our purpose: starting firstly from Public Administration (1: traditional model), secondly to New Public Management (2: NPM, denoting policies aimed to modernize and render more effective the public sector), we may arrive finally to the New Public Service stage (3: NPS, which is coherent with a networked public governance vision). Such an evolution implies a transition from a technical government to a wider and flexible governance philosophy in the ambit of a renewed value\&performance-oriented public sector, which is willing to adopt qualitative principles and where individual employees are free and stimulated to pursue and propose new ideas about how to improve the working of the organization, in terms of efficiency or services. In sum, the quest for public value is the next and urgent challenge for public sector at its various levels: consequently, it will deserve more attention by both policy-makers (central and local public administrators) and researchers. For this purpose, it would be appropriate to come to a kind of public value scorecard aimed at the rational estimate of the expected, or realized, public value created time after time.

At a more analytical-quantitative level, interesting would appear the inter-institutional search for a correlation between the public management value (ie, the value of public administrations) and the value of private institutions that ultimately benefit, with the individuals, from public goods and services.
\end{abstract}

\section{Keywords:}

Public sector, Public Value, Public Management, Government, Governance and Performance, Productivity

JEL Classification: M0O, H83, H0O 


\section{Introductory aspects}

Controlling an economic entity is an important part of the planning function, and this one, in hindsight, can be perceived - in the perspective of governance (Bryson et al. (2014)) - as a fundamental and unifying process. In particular, at a level of strategic analysis, it is arduous and perhaps useless to identify the clear transition when this unitary process becomes exactly or precisely "control".

If (strategic) control is strictly seen as a moment of verification activity, planned and implemented, then the degree of advancement of the resolution, such verification may be conducted not only ex post, but also 'concurrent', and ex ante (becoming - as preventive control - instrument of re-programming) ${ }^{1}$. Nevertheless, the control means in a broader sense business or government dominance, ie the effective capacity to manage resources entwined in a specific system in order to draw benefits and generally produce returns ${ }^{2}$. With the effect, or rather the ultimate goal, to create a lasting and full value.

Control strategy does not apply - within the system of controls - simply monitoring the accounting records and performance of operational management, but through the analysis and investigation about the strategic orientation of the entity. This requires that decisions are evaluated simultaneously as competitive and cooperative choices (coopetition). If the former may be from time to time internalizing strategies (hierarchical) or externalizing (market), the latter will build on the spirit of collaborative alliances, networks, shared control. The decisions in question, intended to change and innovate, positioning itself at the top of the pyramid of Anthony ${ }^{3}$, are generally unstructured and often meet with resistance organization (internal opposing forces).

As mentioned above, the ultimate control lies in the strategic planning capacity to ensure the achievement and maintenance of stable conditions for growth / value generation. Entities today, regardless of whether they are production or consumption voted to, both belonging to the sphere of the private and the public, should aim to create value available to their stakeholder.

In this respect, especially in belief that it is rather sterile to debate about the classification between public and not, we retain that the most significant distinction is to be made simply between "firms" and "no firms". Thus, a given entity or institution - any public or private - can be defined only if such organization meets the conditions of forward equilibrium in time and order. Otherwise it is chaos. Similarly it may be said in principle that, in general, in defense of the possibility of creating value there are the requirements related to efficacy (ability to understand their goals), efficiency (cost-effective use of resources) and, finally, the figurative cost and financial strength.

\footnotetext{
1 See H.I. Ansoff, Implanting Strategic Management, Prentice Hall, Englewood Cliffs, 1984.

2 See A.D.jr. Chandler, Strategy and Structure, MIT Press, Cambridge (Mass.), 1962. R. Normann, Management for growth, John Wiley \& Sons, Chicester, 1977.

${ }^{3}$ R.N. Anthony, Planning and Control Systems: A Framework for Analysis, Division of Research, Harvard Business School, 1967.
} 
Nevertheless, it is known that organizations operating in the public sector have the characteristics of structure and operating profiles which is, in short, an invitation to reinterpret the above said conditions in a targeted way, so as to take into account the strong politicalsocial matters in question and the specific expectations of stakeholders.

The following paragraphs will then desire to dwell particularly on the issue of value creation, with special reference to public administrations and governments.

\section{On the generation and measurement of value for (business / private) firms}

Theories of value have focused historically and preferentially private companies economics. In Italy, the doctrine has polarized the interest particularly with respect to the concept of economic capital value (capitale economico) ${ }^{4}$.

As known, the economic value of firm (economic capital) has got no simple measure of greatness. More precisely, it is the result of a laborious process of collecting and analyzing relevant data and information, knowledge and interpretation of reality company investigated, a thorough study of the structure and functioning of the system and sub-systems in which it is articulated (and, again, the observation and representation of company positioning in its own strategic framework, the definition of the correlations developed by other entities and individuals in the firm-stakeholder relates, the accurate identification of multiple value drivers etc. $)^{5}$.

Generally, it is expected that valuing an entity should ensure the greatest neutrality level possible. Nevertheless, it is not to be ignored that a given amount of value is in some way expression of the fellow who evaluates, since it reflects his technical expertise, approach and misurandi method, experience, and, last but not least, the ability to obtain and reprocess (also in a predictive way) data and information: in one word, his personal "sensitivity" of economic and business valuation. It follows that any assessment is far from being absolute, ie the only one. Relativism and subjectivity inherent in any firm assessment - allowable as long as it does not lead to arbitrariness - is also explained by the abstract nature of the searched value (capitale economico), which is inevitably based on assumptions, forecasts and projections.

From this point of view, the process of supposing an existential relationship between subject evaluator and the object evaluated shapes all the difficulties in establishing all the components of that relationship: indeed, certain elements - even though detected and classified - are not easily at all quantifiable. Eminently qualitative factors (management culture, attitude to risk, barriers to entry, strategic alliances, resources invisible, relational, network, corporate governance, etc.), in fact, in various way affect decision making and ultimately, the monitored firm value.

\footnotetext{
${ }^{4}$ Among others, see the vital contribution of P. Onida, Economia d'azienda, Utet, Turin, 2001 (re-print).

${ }^{5}$ L. Guatri, M. Bini, Nuovo trattato sulla valutazione delle aziende, Ube, Milan, 2005; T. Koller, M. Goedhart, D. Wessels, Valuation : measuring and managing the value of companies, 3rd ed., University ed. - New York, Wiley, 2002; G. Zanda, M. Lacchini, T. Onesti, La valutazione delle aziende, Giappichelli, Turin, 2013.
} 
Coming back to issues relating to public administrations, such difficulties are very considerable, because upstream of the largest metric problems lies a more fluid notion of value, less crystallized than in the case of private businesses.

Nevertheless, it is generally accepted and shareable that public organizations should (at least strive to) create value, specifically named public value.

It must be said - en passant - that in literature on evaluation of companies a key role is still played by the estimation methods based on the flows of economic-financial results (profits, cash flows, dividends), flanked by those approaches based on re-expression of the substance at current values of total or net assets (often indeed are preferred mixed or hybrid methods). Moving on to the field of governments / public sector, is certainly recognized as a priority the need for funding for public goods, and more generally for public services offered; however, is often the case that such coverage is entailed in a transfer to future (eg future generations) with financial burden (public debt and interests) too. This implies, in practice, government deficit amounts that not necessarily lead to a destruction of value, since in such cases you can still create public value. On the other hand, a prolonged situation of this kind - when not sustainable - can determine a crisis (eg think of the spiral of debt-interest) harmful for the institutions and the constituency.

This set, the following section focuses on public value.

\section{About the management of Public value}

The public value ${ }^{6}$ - as a reference value for the community - is reconnected with direct line to the ability of administrations and governments to meet adequately the needs of constituency and create widespread social welfare at the same time. Here the main difficulty on the metric field moves from the observation that the goods and services offered do not identify values for exchange or market, in fact they are paid - with public revenues and expenses - or indirectly through tax collection, or directly through fees or charges, usually of smaller size than the level of real utility perceived by the users / beneficiaries.

Among the ways in which the specification of the concept of public value may find Borgonovi ${ }^{7}$ points the following ones:

- Improving the quality of life (for individuals) and relational quality (ie collective life: for example in areas such as enhancing security, reducing pollution, etc..).

- The creation of positive externalities, ie conditions that improve the exchange values of other subjects / entities and thus are accounted for in their budgets.

- The value creation subsequent means of transport "faster and more comfortable", the "defense of the territory" (with the police, with more controls against crime, vandalism or terrorism), etc.

\footnotetext{
${ }^{6}$ See E. Borgonovi, Principi e sistemi aziendali per le amministrazioni pubbliche, Egea, Milan, 2006, p. 48.

7 Ibidem, p. 48.
} 
Among the methods - direct or indirect - aimed at measuring public value instead there are:

- Analysis of cost / benefit;

- Value approach-opportunities (in order to calculate the equivalent, hypothetical market value);

- Measurement of willingness to pay by the beneficiaries / payers (willingness to pay);

- Analysis and differential levels of satisfaction.

As anticipated, theories traditionally are able to estimate the economic value of firms (companies). Above all stands the theory of shareholder value (SHV), which, however, has gradually been subject not only to several methodological refinements (for example the recent Economic Value Added method, the method of incremental opportunities, determinations of strategic or potential capital, etc.) but also to extensions of conceptual roots in order to reflect different instances from shareholders or owners of corporate capital (extended SHV). In this regard, using an approach oriented to the stakeholders in general ${ }^{8}$, it seems possible today, as desirable, to decline the issue of firm value in light of the ethical or social responsibility, eg. calling into question the configuration of value-added period estimates (which in itself has great potential for information, as implemented through appropriate reporting often confluent in budgets or social sustainability).

It is believable that the public value is somehow related to the latter configuration of values precisely oriented to the social dimension of firms and their responsibilities towards stakeholders and its environment.

The generation of value, however, much depends on how companies are managed (managerial quality: which is thus pre-requisite for the government of the value).

As concerns businesses, in cognitive terms, are important the various strategic models ranging from that of Porter (focusing on business strategy and value chain) to the model of value-based management ${ }^{9}$. From the point of view of the Government of public administrations, it should be given emphasis to the recent transition from an ideal institutionalbureaucratic logic of government (aiming to classic goals of equity, fairness, neutrality) however, innovated by the well known processes of corporatization of public agencies and the digital technologies (ICT and e-Gov) - to the most advanced philosophy of public governance (see Bryson et al.).

\footnotetext{
${ }^{8}$ For strategic aspects, see: R.E. Freeman, Strategic Management: A Stakeholder Approach, Pitman, Boston, 1984.

${ }_{9}$ M.E. Porter, Competitive Strategy: Techniques for Analyzing Industries and Competitors, The Free Press, New York, 1980; see also, K. Andrews, The Concept of Corporate Strategy, Irwin, Homewood, 1980. When applying this model for example to a local authority, primary activities should be considered the purchase of goods / services, operating expenses and transfers operated for the benefit of other organizations or persons. Overheads and support expense (relative to joints, boards, DG, secretariat, etc.) instead constitute support activities. This analysis could then be declined for various sub-organizations involved in the management of the local authority (public works, safety, education, culture, sport, personal services, roads and transport, land management, social-economic development, taxes). Regarding local governments and their innovation processes, see N. Angiola, Percorsi di modernizzazione dell'azienda pubblica locale, ESI, Naples, 2008.
} 
In this evolutionary transition, a major role is played by the New Public Management, which has had the clear effect of a significant re-thinking of the old logic of administration, finally giving space to decentralization, organizational skills, vision of the citizen-client, separation of financial and operational dimensions (as well as between policy and management), progress in managerial processes through planning and control multiple instruments (activity-based costing / managing, benchmarking, SWOT analysis, balanced scorecard, ...), contractualism more or less stringent with easy evidence of accountability, legitimacy and performance.

If this line (NPM studies) is largely a good framework to achieve effectiveness and efficiency, it is believed that the newer approach to governance (in particular the governance network) emphasizing, especially, principles of subsidiarity ${ }^{10}$ and interdependence, functions of active citizenship with the right expression of voice, the centrality of relational goods and the trust (more than transactions), coordination and inter-firm collaboration (partnerships), intersubjective civil society for the benefit of all (rather than market ) - may be today a way more immediate, responsive and progressive for creating public value. This perspective points indeed on three interrelated dimensions, the internal one (in which the same new public management provides sophisticated tools and suitable supports), the external one (relative to the governance of outsourced services and activities, focusing on rights and duties with special regard to minimum levels of quality) and the inter-institutional one (founded on multiple non-hierarchic group or reticular relations between agencies and entities at various levels).

Among the several managerial control tools available to the public, deserves at least a brief mention the balanced scorecard (BSC introduced by Kaplan and Norton initially for companies in private sector for measuring intangible benefits). In this framework, the assessment of corporate performance is not reflected solely by economic and financial perspective, but from a broader range of indicators belonging to different spheres, namely (in addition to the traditional economic-financial dimension) to the customer's perspective, to the internal processes and innovation and learning perspective. In essence, the ultimate goal of the BSC is to balance the known economic and financial indicators (as cash flows) with other value drivers (non-financial indicators of value) with the consequence to shed light on the real possibility of creating value in the future, accordingly to multiple perspectives and useful analysis. It goes without saying that often evaluations of company performance determine results that are hardly measurable or qualitative judgments, not always properly or adequately quantifiable.

More and more the BSC technique has been implemented in companies' management also for the purpose of a better and more structured formulation of strategies value oriented at various levels of organization. For what matters most here, BSC seems (still) a promising tool for strategic control to be used in evaluating the performance of both the companies and public administrations, being able to provide valuable elements to simultaneously check the economic and financial programs, the level satisfaction of citizens, providers, social organizations, associations, etc. (basically the consensus of stakeholders) ${ }^{11}$, the effectiveness

\footnotetext{
10 It should be remembered that the principle of horizontal subsidiarity requires public authorities to have a step back compared to private operators to the extent that private operators know how to realize a more effective and efficient service. The principle of vertical subsidiarity instead plans to bring the decision-making power more closely to the needs of target communities (as an alternative system to the centralized administration).

${ }^{11}$ It could be said that the perspective of the customer-user is not fully sufficient; indeed, it should be accompanied by a fifth, additional, analysis dimension, the institutional and social one.
} 
and efficiency with which internal processes are supervised and finally the capacity in terms of knowledge and learning of human resource engaged to the business system (so-called human capital).

Especially in view of creating value, higher is the strategic potential of BSC in the sense that the technique in question might better ${ }^{12}$ : disclose the intent and the strategic vision of the company (through clarification of strategy maps), focus on the most critical factors of success (revitalizing existing resources), provide the basis for a more complete business information (management information system), strengthening the processes of feedback (learning organization); ultimately, help the public organization to align its strategy and, further upstream, to its mission (public value creation). It must be said that BSC is recorded in several local governments.

Beyond the theoretical and methodological models and constructs, we must not lose sight of the fact that every business is done, at the base, of ideas and men. A crucial factor that generates the organizations' value is to be found in their human capital (which occupies a prominent position in the system of firms intangibles, the real generators of performance and value). Therefore, any effort to give the measurement and disclosure to such aspects may be useful.

On the communication / reporting filed of analysis, a valid instrument is also found in the determinations of the value added accounting matrix (an important part is inherent in corporate staff, however, it is undisputed that it refers to the Marxian notion of surplus value or to that of Schmidt). This financial measure, is an expression of the difference between the value produced by the public organizations - that is not achievable through the sale, but inherent in collective and / or individual consumption - and external costs required for the same activities (goods and materials, services, other external expenses).

Examining the "profit and loss" account of a public administration, it results that the value of production is primarily given by the summation of the proceeds/incomes of the accounting period (usually for taxes, transfers, rates, etc..); this value, curtailed by both the costs of external factors and incomes that do not finance specific services, is subject to adequate distribution between services, with the effect of signaling efficiency (ratio of activities carried out / resources consumed) and effectiveness (satisfaction reached) levels. For the assessment of each service offered, it is therefore important to determine the income and expenses specifically attributable (or ad hoc transfer tax revenue, return on capital, credit, etc.).

The analysis of the value added may be a mode of control (by detection) only valid if a correct reclassification of "income" is done. Private companies - as known - often employ this technique in the preparation of social reports, and it would be well recommended in the public sector - also in support of strategic control function - to monitor the value added services.

From the metric point of view, however, the technique of value added - since needs margins, reflections and qualitative judgments, if you intend to start from here to catch the wider concept of public value - rests mostly on the economic -financial field. For this reason, may be

12 M. Romano, M. Taliento, La valutazione del capitale umano: stato dell'arte e prospettive di analisi, in AA.VV., La conoscenza nelle relazioni tra aziende, FrancoAngeli, Milan, 2008. 
convenient some further insights on the issue of public value and for this purpose reference literature and foreign practices are welcome.

\section{Public value management, Public sector value. State of art and advances}

In the previous section, the network governance of public sector has been seen as a developmental phase subsequent to that of the government and the new public management.

Stoker ${ }^{13}$, among others - ascertaining the relative decline and certain weaknesses of the NPM -, set out to identify the most appropriate management approach to manage a complex public entity in the light of network governance / PVM (public value management). The latter approach, based on relational systems of dialogue and exchange, had indeed been introduced by Moore ${ }^{14}$.

In short, central to the public value dynamics are people (human resource). They, however, rather than by traditional rules and incentives, seem better motivated by active involvement in a network of institutional relationships and partnerships with various entities, in a context of mutual respect, sharing and learning.

It was Moore himself to auspicate the manager of the public sector to create a value system founded on a more development-oriented services offerings, accordingly to a sort of governance philosophy capable of generating value through a careful identification of the constituency expectations and the accompanying ethical and social responsibilities ${ }^{15}$. In other words, while companies tend de facto to pursue, more or less consciously, the general objective of maximizing the (private) economic value, public administrations would be directed toward the widest public (social) value. More precisely, Moore brought the concept of strategy

${ }^{13}$ G. Stoker, Public Value Management - A New Narrative for Networked Governance?, in The American Review of Public Administration, Vol. 36, n. 1, 2006.

14 M.H. Moore, Creating Public Value: Strategic Management in Government, Harvard University Press, Cambridge, 1995, and also, M.H. Moore, S. Khagram, On Creating Public Value. What Business Might Learn from Government about Strategic Management, Working Paper n. 3, Harvard University, march 2004. See furthermore: M. Cowling, Measuring Public Value: The economic theory, The Work Foundation, London, 2006; P.M. Jackson, Public Sector Added Value: Can Bureaucracy Deliver?, in Public Administration, n. 79/1, 2001; and G. Kelly, G. Mulgan, S. Muers, Creating Public Value: An analytical framework for public service reform, UK Government, Cabinet Office, London, 2002. The last mentioned Authors state that: "Public value provides a broader measure than is conventionally used within the new public management literature, covering outcomes, the means used to deliver them as well as trust and legitimacy. It addresses issues such as equity, ethos and accountability. Current public management practice sometimes fails to consider, understand or manage this full range of factors" (p. 3).

15 In particular, it should be identified as accurately as possible the desires and perceptions of people. In relation to goods and services offered by public institutions, the aspirations of the citizens are of two kinds: public goods, even if general and indivisible, individually desired; political aspirations, reconnectable to aggregated social conditions (which are reflected in the fair distribution of rights, opportunities - including economical -, obligations and responsibilities, as well as the desire not to waste costs in resources coming from taxation). In order to debate on the subject of the value, Staley has also clarified the need to maintain separate public value from public's value: «For example, in relation to public health policy that aims to reduce smoking, a debate on public values would revolve around a discussion of the limits to government action to improve health through smoking cessation. It would consider normative issues such as "would a ban on smoking in public places be acceptable?" And "is it acceptable to place a heavy tax on cigarettes?". In contrast, the public's values are simply what the public thinks about these issues at any given point in time» (cit. in B. New, J. Neuberger (ed. by), Hidden Assets: Values and decision making in the NHS, London, King's Fund, 2002). 
in the public sector, which is based on the assessment and production of public value by means of a simple heuristic scheme called strategic triangle. It, in essence, consists of three basic elements (see Fig. 1):

1) the definition of the target measure of public value to be produced by the public organization, and the same one vision of public value (to clarify - communicating it - and share);

2) the sources (ie groups of subjects "investors"-stakeholders) of legitimacy \& support for authorization (on the political and social, in terms of reputation, credibility and consensus) and provision of services (including, but not limited to, materials necessary for the funding manager in order to create public value);

3) the possession and exploitation of real operational capability (including new investment, innovation, alliances and partnerships with other persons or entities located outside of organizational boundaries ${ }^{16}$ ).

\section{Public value (vision)}

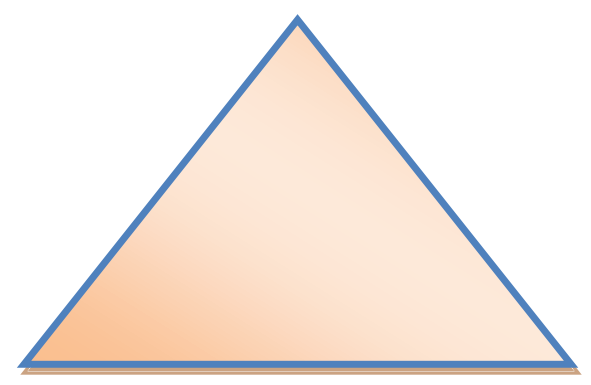

\section{Legitimacy \& support}

\section{Operational capability}

Figure 1- Strategic Triangle (Moore)

In a nutshell, "The strategic problem for public manager thus came to be: imagine and articulate a vision of a public value that can command legitimacy and support, and is operationally doable in the domain for which you have responsibility"17.

\footnotetext{
${ }^{16}$ For example, the administrator of a school or a public university can assume an approach that strictly deals with what falls within his own direct control; he can expand his horizons, eg. soliciting voluntary contributions of various kinds, to relatives or parents of students or to generous companies which insist on the territory, in order to improve the mode of educational offerings, applied research, spin-offs, etc. See S. Black, Do Better Schools Matter? Parental valuation of elementary education, in Quarterly Journal of Economics, Vol. 114, 1999.
} 
Moore, according to this, emphasizes the importance of understanding of the aspirations of citizens, which in practice should be reassured regarding the proper use of resources systematically used (rather than the degree of fulfillment of specific programs whose beneficiaries are only certain, limited, subjects). The public managers are therefore authorized to manage public resources in order to pursue collective goals by specific means - and with methods that undergo adaptations in itinere because of ongoing physiological changes in context - in exchange for the promise to create public value (that meets both effectivenessefficiency and equity, but also of ethics and accountability criteria).

On the basis of such assumptions, it is easy to imagine the difficulties inherent in the multiple dimensions of public performances, especially from the metric ones (from the point of view of equity as an outcome); we also understand the importance to resize the blind confidence in business-like results systems (in particular if economic-financial) instead of requiring dashboard of indicators tuned for public organizations, eg. along the lines of a modified BSC ${ }^{18}$.

In this perspective, we should first rebuild a national strategic framework and the map of stakeholder (who need peculiar meta-economic information), and second, outline the various dimensions of public performance, that seem characterized by three key variables (inputs, outputs and outcomes) to steer accordingly to the above mentioned criteria.

With primary reference to public service organizations, Cole and Parston ${ }^{19}$ have elaborated for Accenture 20 - a simple working control-value model, called Public Service Value model, with the aim of supporting public managers in the evaluation of the results achieved (performance) and the public services value perceived by users. This model consists of placing two priority needs: (a) the rational containment of public expenditure in respect of budgetary constraints; (b) the growing expectations of the citizens in terms of improving the quality of services.

Both set, the public managers must be able to measure the performance of public administrations, assessing the results achieved (ie impacts on the community in terms of social value, available to the citizen and the territory) compared to the resources used / allocated. Therefore, the two key variables for the PSV model are (a) the efficiency of expenditure and (b) excellence in the results: while stepping up a and b (without predetermining, as often happens with private organizations, the rigid target levels, fixed and unique), the public organizations create social value.

The measurement process of the PSV is designed, specifically, to:

- Identify a range of outcomes that the organization believes the public want to achieve;

- Calibrate (filtering \& weighting) the results with reference to the priorities of citizens (known by inquiring about what constitutes value for them), taking account also of similar experiences;

\footnotetext{
17 M.H. Moore, S. Khagram, On Creating Public Value. What Business Might Learn from Government about Strategic Management, cit., p. 9.

${ }^{18}$ An interesting application of the BSC in the public sector may be found in the administration of the British Library (national library of the United Kingdom).

19 M.I. Cole, G. Parston, Unlocking public value: a new model for achieving high performance in public service organizations, John Wiley and Sons, N.Y., 2006.

${ }^{20}$ In collaboration with the Harvard Kennedy School of Government and the London School of Economics.
} 
- Introduce measures of economic efficiency (opportunity-cost) to satisfy the interest of the constituency to the use of public resources without waste;

- Prove to be a managerial tool 'customizable', so as considering organizational and territorial specificities and peculiarities;

- Not even replace the control systems and strategic management background, but assist, implement or complete them;

- Allow a time (of a certain public organization) and spatial (among several public organizations) comparison ${ }^{21}$;

- Be applied not only to the government, even to non-profit and private firms of public utilities.

In summary, Cole and Parston point out that "public service value is about more than simply attaining outcomes, and it is about more than just reducing cost; it is about doing both in a balanced fashion and understanding the strategic trade-offs available along the way"22. The application of such an elastic model aims at an improvement of the positioning of public organization monitored within the two-dimensional matrix shown below (Fig. 2$)^{23}$.

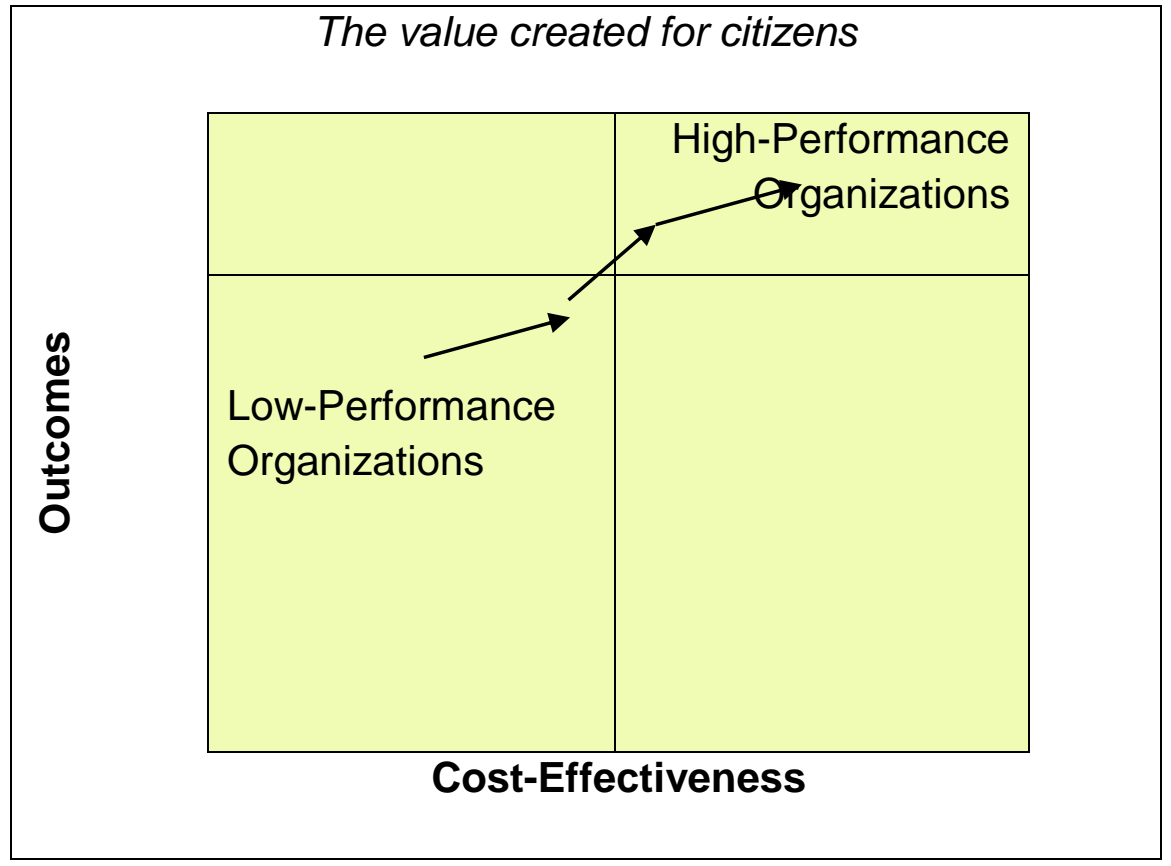

Figure 2 - The PSV model (Cole \& Parston)

\footnotetext{
${ }^{21}$ Among the main applications, we have to recall the following: the Metropolitan Police in London, the national security agency in Spain, the city of New York and the tax agencies of some states (U.S.). In order to spread the culture of public value, Accenture has also recently established the Institute for Public Service Value.

22 M.I. Cole, G. Parston, Unlocking public value: a new model for achieving high performance in public service organizations, cit., pp. 63-64.

23 Ibidem, p. 64.
} 
The model, accordingly to a multi-step approach, is based on four building blocks to which follow the development phase of outcomes and metrics (see Fig. 3$)^{24}$.

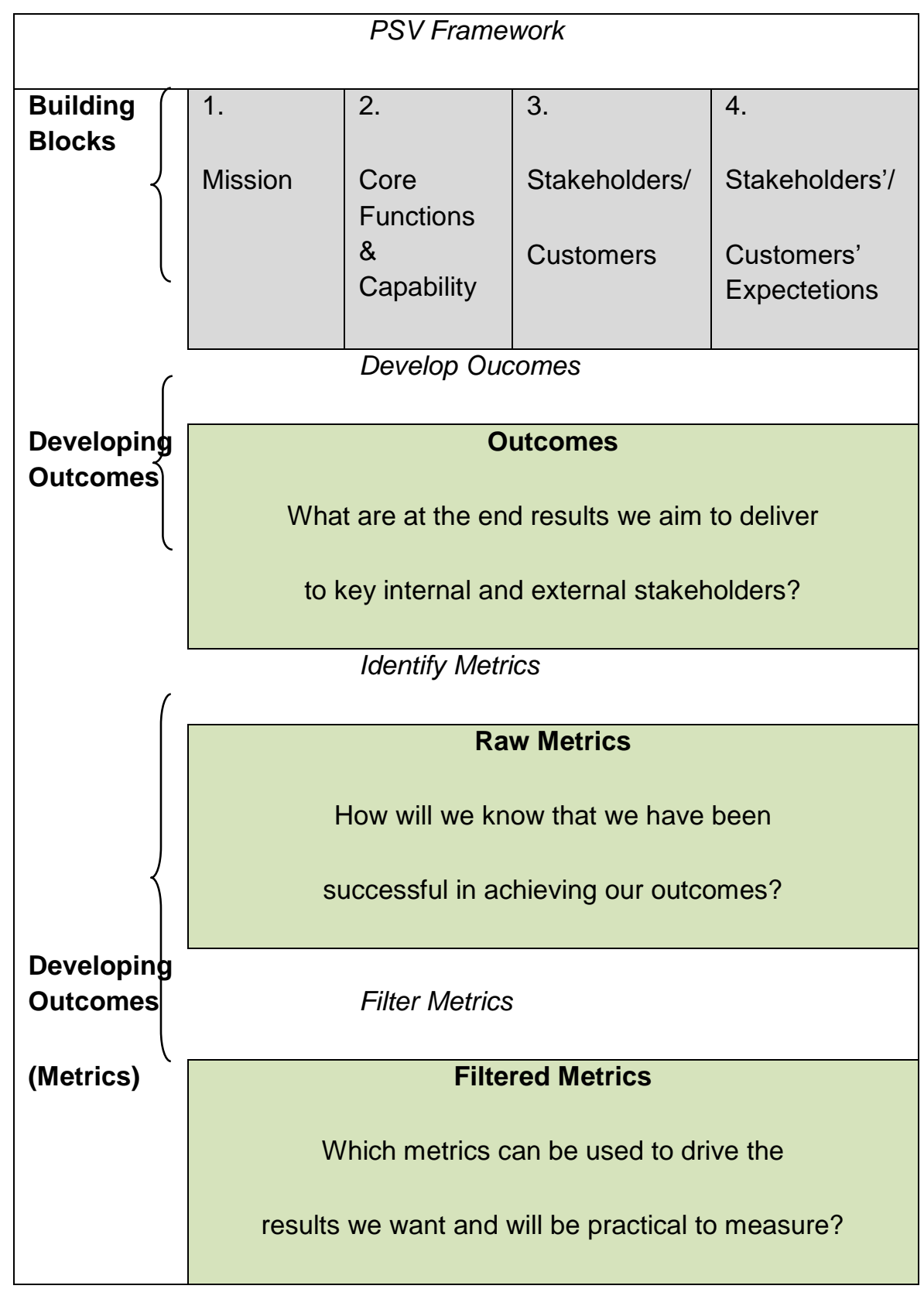

Figure 3 - PSV model building blocks and developments

It is superfluous to underline that the most controversial aspect is the one relating to the quantization of the public value created. It is believable that the possible range of metric indicators must firstly be accepted by the constituency. It is perhaps not useful to search for a given organization a deterministic single indicator of quality or outcome (unless it is a complex index of synthesis); however, from time to time the public administration will find a set of

24 Ibidem, p. 67. 
shared indicators that signal opportunities for intervention and continuous improvement (by means of an examination of: "scale/proportion/rate": eg. rate of digitalized services, mortality rates, etc..; "division/ratio" as number of crimes or new infrastructure in a year, etc..; "continuous variables": eg. average age of graduates, average hospital stay of patients healed, etc..; "dummies": eg. fuzzy ${ }^{25}$ satisfaction ratings low, medium, high; transport deemed more or less fast and comfortable, etc..).

On the basis of public policy initiatives put in place, then experienced firsthand, and performance reported, citizens may be better able to decode the actual or potential impact of the public governance on their own status and satisfaction (current or future, individual and collective).

To finish, it is worth reporting that several scholars have lately deepened these interesting arguments around value(s) in public administration research. The renewed interest has become paramount.

In hindsight, two recent strands seem to emerge, even differentiating themselves from new public management (West \& Davis 2011; O'Flynn 2007); they concern: 'public values' (plura); and 'public value' (singular).

The former strand regards questions of administrative theory and praxis, organization and governance of entities that produce and pursue public goals (Rutgers 2008; Bozeman 2002; Beck Jørgensen 2006). The latter, more complete, extended and popular strand, is the one originated by the above mentioned studies carried out by Moore on public value as a flow of social welfare (Moore 1995, 2009). This approach regards evaluative questions on policy outputs rather than organizational/governance questions (former).

West and Davis assert that these two strands "differ in substance and orientation and in the extent to which they have pervaded practice" (p. 227); at the same time, they highlight the path of a new pragmatic approach to public values questions to critique a tendency in theorizing towards universalism and abstraction (new pragmatism, see ex multis Latour 2005).

Also Rhodes and Wanna (2007) have criticized Moore's argument for public value creation, claiming that it may appear too unrealistic and, to a certain extent, platonic. On the contrary, Colebatch (2010) fairly defends Moore's framework remarking that we have to go beyond conventional role definitions, and hence capture the gist of the value constructive process. The Author acknowledges that the lesson Moore draws is that public managers should be active in seeking out ways of collaborative action which will achieve an outcome and yield

\footnotetext{
25 For fuzzy approaches to economic valuation, see M. Taliento, Ai confini del terminal value. Complessità, incertezza e sfocature estimative nelle valutazioni d'azienda in chiave fuzzy, Giappichelli, Turin, 2008. About public organizations / administration, has been stated: "At the level of measurement, scientific progress was achieved in part through the development of sophisticated measurement technology that enabled primary qualities of objects such as weight, size, temperature and density to be measured accurately and reliably. The ontology underlying mainstream science is (usually) one in which reality exists and is driven by laws of cause and effect, and its epistemology is one in which this reality can be determined through empirical study free from subjective judgment. However, the application of these principles to the social world has always been rather more complex and contested, partly because this involves the study of subjective qualities (such as pain or satisfaction) and broad abstract notions such as intelligence or democracy". D. Hills, F. Sullivan, Measuring public value 2: Practical approaches, The Work Foundation, London, 2006, p. 15.
} 
value. The debate is still on and lively. Moore's doctrine appears always central, although newer interpretations and interesting applications are taking place.

Moreover, after ascertaining the substantial absence of a systematic review of the literature on public value provenance, empirical basis and application, Williams \& Shearer (2011) sought to fill such extant gap by providing a critical introduction to public value and its conceptual development ("past", "present" and "futures") and therefore by presenting the main elements of the published literature from 1995 (ie, the date of Moore's seminal work) ${ }^{26}$ onwards. More in detail, the cited Authors (complaining about some lack of clarity over what public is), argue that, while the aspirations for the public policy makers can be easily realized, on the other hand a concerted process of research, debate and application of public value is still required. The main concerns highlighted are those over the apparent silence on questions of power and heterogeneity, as well as the difficulties for empirical tests in such fields.

A new frontier tries to intersect the boundaries of public and private institutions and dynamics. For example, Kivleniece and Quelin (2012) investigate the value accumulation and capture mechanisms embedded in public-private ties through a theoretical framework conditioned by partner opportunism and external stakeholder activism.

Above all, for our purposes, Bryson et al. (2014) finally confirmed that a New Public Administration Movement (a response to the challenges of a networked, multisector, no-one-wholly-in-charge world and to the shortcomings of previous public administration approaches) is emerging to move beyond traditional public administration and New Public Management. In the new approach, values beyond efficiency and effectiveness - and especially democratic values - are prominent. In this framework, the Government has a special role as a guarantor of public values, yet citizens as well as businesses and nonprofit organizations, are also important as "active public problem solvers". Value-related issues in the new approach are highlighted and present an agenda for research and action to be pursued if such new approach is to fulfill its promise.

As a consequence, Bryson et al. (2017) also indicated the way towards a multi-actor theory of public value co-creation. They have suggested changes to the theory of public value and, in particular, the strategic triangle framework, in order to adapt it to an emerging world where policy makers and managers in the public, private, voluntary and informal community sectors have to somehow separately and jointly create public value (one set of possible changes concerns what might be in the centre of the strategic triangle besides the public manager; additional suggestions concern how multiple actors, levels, arenas and/or spheres of action, and logics might be accommodated; at last, possibilities are outlined for how the strategic triangle might be adapted to complex policy fields in which there are multiple, often conflicting organizations, interests and agendas; in other words, how might politics be more explicitly accommodated). A specific lens and a test of "public value in politics" achievement with democracy and efficiency (a facet of Moore's original framework that remains its most contested) is given - under both a normative-advisory institution (as in USA), and a mechanistic-costing (as in Canada) approach - by Chohan \& Jacobs (2017).

${ }^{26}$ Essentially issued on: American Review of Public Administration; Australian Journal of Public Administration; International Journal of Public Administration; Policy and Politics and Public Administration. 
Scott et al. (2016), instead, focused on internet technology and found that measuring the success of a eGovernment 2.0 system is related to how citizens perceive their value. They recently proposed a Public Value-based (Net Benefits) theory in order to encompass three essential success or value clusters: efficiency, effectiveness and social value.

At a specific analytical-quantitative level, Taliento (2016) provided an inter-institutional search for a cross-country correlation between the public management value (ie, the value of public administrations) and the value of private institutions that ultimately benefit, with the individuals, from public goods and services. The possible impacts of public domain on the quality of private institutions and relating markets functioning (financial, labor, goods, technology) are identified through aggregate statistics. The study concluded that ceteris paribus public value (esteemed in terms of quality of public institutions, as supported by infrastructural entrepreneurship) and private value (quality of private entities, even specifically expressed by market efficiency enhancers) are strictly positively associated each other in the global economy. The higher the former, the higher the latter. ${ }^{27}$ The positive correlation appears even stronger in advanced economies, their efficiency indicators being intensified.

Mintrom \& Luetjens (2017), anyway, asserted that, to guarantee a positive effect and concrete outcome, policy design and public management should be tightly connected, so that implemented public policies achieve intended outcomes. Unfortunately, real policy designers often pursue their activities with limited awareness of how citizens and service managers experience current public programs. Therefore, a focus on creating public value offers a way to tighten the connection between policy design and public management, emphasizing three aspects of public management: delivering services, achieving social outcomes, and maintaining trust and legitimacy. In this way, the pursuit of public value calls for policy designers to listen closely to stakeholders, engage them in creative conversations, and draw on their situated expertise to guide policy development. This is expected to improve the fit between original policy intentions and the delivery of public services.

\footnotetext{
27 See Taliento (2016): «With reference to the specific topic of public (and private/public) entrepreneurship stricto sensu conceived, particularly when applied to public infrastructures settlement, we can assert that our expectations in terms of positive impact on competitiveness have been empirically verified: so we can confirm (in line with WEF 2013 assumptions) that extensive and efficient public infrastructures are significant in stimulating an effective functioning of the economy, because they can co-determine the location of economic activity and the kinds of activities or sectors that can develop within countries. Moreover, well-developed infrastructures will reduce the effect of distance between regions, integrating markets at low cost; additionally, a well-developed transport and communications network becomes a prerequisite for the access of less-developed communities to core economic activities and services, while effective modes of transport can enable all the enterprises to get their goods and services to market in a secure and timely manner, facilitating the movement of workers to the most suitable jobs. Finally, the industry is favored by electricity supplies that are free from interruptions and shortages (so that businesses and factories processes are not impeded), while a solid and extensive telecommunications network allows for a rapid and free flow of market information, which will increase overall economic efficiency by facilitating business communication and decisions to be made taking into account all available relevant information (ICT).

Public entrepreneurs (along with private entrepreneurship, especially whenever their cooperation is de rigueur) are then solicited to improve behaviors and programs / activities (recognizing that new rules established by the public entrepreneurship commonly still follow the private model, borrowing the relating skills, strategies, instruments/tools, cultures) in order to achieve a growing level of competitiveness. Public innovation, proactivity, creativity / novelty, alertness to opportunities, judgmental decision making abilities, as well as the establishment of new, modern public organizations/activities, seem to help gaining major outcomes for the benefit of everyone (both economic and civil society participants).

Ultimately, in line with our findings attesting the positive associations above mentioned (the higher the public value, the higher the competitiveness of economies), value-oriented public investments and improvements may figure to us as the invisible, pulsing heart of private institutions and principal marketplaces; whose "trust in public" solidity and soundness (ie, public value) appears able to significantly affect their own structure, functioning, relationships and performance (ie, private, or blended, worth)».
} 


\section{$5 \quad$ Final remarks}

Monitoring the process of value generation is essential for the strategic management of public administrations (as for private companies). The value is first conceived, created, then measured (so-called public value) and finally distributed among stakeholders/citizens (enhancing their quality of life).

The interesting theories of value, as seen, traditionally arise in relation to private companies (whose economy is nodal for transactions and their price); with time, however, has grown the need for rehabilitation of the relative evaluation approaches to be applied - although modified - to public administrations (where the cornerstone is the relational wealth and, ultimately, the citizens' consent).

The private notion of economic capital is in other words not strictly proper in the public sector (with some exceptions: think of the appropriate application for the estimation of the economic capital to peculiar public entities such as public utilities firms: methods as EVA are very suitable for the utility companies of the energy chain, water supply, urban sanitation, etc.). Mostly the notion of public value assumes remarkable importance on a higher ethical-social (and political) level.

Nonetheless, it should however be considered inherent to the phenomenon "firm" (albeit of public nature) the cardinal principle of sustainable e durable equilibrium. Moreover, in the case of public administrations, such a basic requirement is to be understood as the ability to guarantee, in the longer term, the economic and social growth of the community expressed by the balance between sustainable "value" created through qualitative and quantitative achieved results and "value" absorbed in the performance of public management.

The trend in equilibrium must be ensured even upon the financial management side of public affairs. It does not go unmentioned that any financial imbalances, though sometimes temporary, will not uniquely determine the judgment (which may be incorrect) about the public value created. Thus, the introduction of the concept of public value, linked to effective methods and measurement systems, can help avoid the creation of improper equivalence between deficit (surplus) accounting and presence (or absence) of waste and inefficiency, to give estimates to different administrations which, with the same accounting result, produce a very different public value.

The most critical moment lies in the measurement of public performance (and differentials of public value grades), which is in many ways - especially in terms of technical and operational models - still a challenge for research in public sector organizations ${ }^{28}$. The measurement of outcome appears here precondition to satisfy growing needs for transparency and

\footnotetext{
${ }^{28} \mathrm{E}$. Borgonovi, Principi e sistemi aziendali per le amministrazioni pubbliche, op. cit., p. 49. Therefore, the Author clarifies: "Un corretto concetto di valore pubblico consente per esempio di valutare negativamente politiche che hanno per risultato la riduzione di un milione di euro della spesa pubblica ma con la riduzione del valore pubblico di tre o cinque milioni di euro o, politiche che determinano un aumento di spesa di due milioni di euro (anche se finanziati) con la produzione di valore pubblico inferiore ai due milioni di euro o, addirittura, insignificante o negativo" (For example, a correct concept of public value allows for a negative assessment of policies that result in a one million euro reduction in public spending but with a reduction in public value of three or five million euro; or of policies that result in an increase in expenditure. two million euros (even if financed) with the production of a public value of less than two million euros or, even, insignificant or negative) (pp. 48-49).
} 
accountability and to streamline the procedures for concrete response (indicating margins for improvement) to the expectations of citizens (revealed, as appropriate, through direct survey on the degree of satisfaction for services, consultations and public meetings, other opinion polls, focus groups, citizen's panel, committee work, referendums, etc..).

In the perspective of strategic control/management, however, the result (in the sense of "value creation") is not only knowable but made conveniently and properly governed in a complex and dynamic perspective of "processes".

In recent years, the scientific debate about the performance measurement movement, gradually merged in the performance management of public organizations thought, has produced a sort of evolution in stages, and these are resumable in the transition from models of management based upon expenses and costs, to the management model of responsibility, then arriving to the quality management government model and at last to the public value model.

Such an evolution towards management schemes public value oriented, as seen, should also be reinterpreted in the light of recent developments registered in the field of public governance (which has many elements of divergence with respect to aspects of government ${ }^{29}$ and even of public management, especially if Anglo-American, characterized by specialization and internal micro perspectives).

That said, it is believable that today a proper management of public value can only be realized within an appropriate public governance, rectius of networked type, based on the existence of dynamic, open and complex relationships (not necessarily dominated by certain individual actors rather than other). Moreover, the ultimate goal of governance - both in the private and public sphere - may be found precisely in the generation of total value (in some way coproduced by networked entities) available for several stakeholders.

In the case of public sector, assuming particular importance both the multiple quality services provided to the constituency as the relationships and interactions established and engaged in economic, political and social field, the public governance in speech goes to represent the new structures and processes of factual public organizations which (considered not only in terms of micro, individually, but also meso, as an integrated system of government, and macro, as an active partition of the environmental system in which they operate), enable the supply - with words of Denhardt and Denhardt 30 - of a new public service outside-oriented that seeks to recover also the reputable ethical dimension of human action, individually and collectively considered ${ }^{31}$ (the following table summarizes the essential, theoretical and behavioral, profiles of the aforementioned analysis prospects ${ }^{32}$ ).

\footnotetext{
29 The evolution from government to governance can be explained (among other causes) by the weakening of the State. Schick dares to translate the public governance with the expression governing without (national) government. A. Schick, The Performing State: Reflection on an Idea Whose Time Has Come but Whose Implementation Has Not, in OECD Journal on Budgeting, Volume 3, n. 2, 2003.

30 R.B. Denhardt, J.V. Denhardt, The New Public Service: Serving rather than Steering, in Public Administration Review, Vol. 60, n. 6, 2000, pp. 549-559.

31 See, above all, M. Meneguzzo, Dal New Public Management alla public governance: il pendolo della ricerca sulla amministrazione pubblica, in Azienda Pubblica, n. 6, 1995. Of course beyond the realm of management and
} 


\begin{tabular}{|l|l|l|l|}
\hline & $\begin{array}{c}\text { Public } \\
\text { Administration } \\
\text { (traditional) }\end{array}$ & $\begin{array}{c}\text { New Public } \\
\text { Management }\end{array}$ & $\begin{array}{l}\text { New Public } \\
\text { Service }\end{array}$ \\
\hline $\begin{array}{l}\text { Primary } \\
\text { theoretical } \\
\text { and } \\
\text { epistemologic } \\
\text { al foundations }\end{array}$ & $\begin{array}{l}\text { Political theories, } \\
\text { socio-political } \\
\text { interpretations } \\
\text { supported by a } \\
\text { social science } \\
\text { (sometimes } \\
\text { naïve) }\end{array}$ & $\begin{array}{l}\text { Economic theory, } \\
\text { more } \\
\text { sophisticated } \\
\text { dialogue based } \\
\text { on a matrix of } \\
\text { (neo) positivist } \\
\text { social science }\end{array}$ & $\begin{array}{l}\text { Democratic } \\
\text { theories, } \\
\text { cognitive } \\
\text { approaches } \\
\text { (positive, } \\
\text { interpretive, } \\
\text { critical and } \\
\text { postmodern) }\end{array}$ \\
\hline $\begin{array}{l}\text { Rationality } \\
\text { and prevailing } \\
\text { models of } \\
\text { human } \\
\text { behavior }\end{array}$ & $\begin{array}{l}\text { Synoptic } \\
\text { rationality,'admini } \\
\text { strative man' }\end{array}$ & $\begin{array}{l}\text { Technical- } \\
\text { economic } \\
\text { rationality, } \\
\text { 'economic man' } \\
\text { or selfinterested } \\
\text { decision maker }\end{array}$ & $\begin{array}{l}\text { Strategic } \\
\text { rationality, } \\
\text { multiple tests } \\
\text { of rationality } \\
\text { (political, } \\
\text { economic, } \\
\text { organizational) }\end{array}$ \\
\hline
\end{tabular}

Table 1 - Prospects for a comparative analysis: Public Administration, from the old philosophy to the new public service framework

In light of the above, the development process (actually in progress) of techniques for measuring the performance of public organizations, then their public value, may provide new information useful to improve the skills for their government and management and to support their governance and accountability of public management with respect to both the political sphere (upstream) and citizenship, ie individuals, groups and communities of users of the public goods and services that are provided or regulated (downstream) ${ }^{33}$.

In conclusion, the strategic control on public administrations seem to be able to draw new lymph from a careful analysis of values of their policies and strategies. Such an analysis especially in line with Bryson et al (2017) framework - is also capable of implementation at the technical-operational level by developing a kind of public value scorecard (or similar

services offerings the public governance should refer to the area of policy making, public policy (steering) and to the inspiring, fundamental, indispensable, democracy.

32 See also for further details: R.B. Denhardt, J.V. Denhardt, The New Public Service: Serving rather than Steering, cit.; see also G. Kelly, G. Mulgan, S. Muers, Creating Public Value: An analytical framework for public service reform, cit., p. 10.

${ }^{33}$ Which leads on the one hand to a more correct definition of the relations of coordination and distribution of powers between the political bodies and managing bodies; on the other hand to a more detailed analysis of needs and satisfaction levels of individual and collective of citizens served. 
instruments) ${ }^{34}$ aimed at the rational estimate (based on qualitative and quantitative) of the expected, or realized, public value created time after time ${ }^{35}$.

\section{References}

Andrews, K. (1980), The Concept of Corporate Strategy, Irwin, Homewood.

Angiola, N. (2008), Percorsi di modernizzazione dell'azienda pubblica locale, ESI, Naples.

Ansoff, H.I. (1984), Implanting Strategic Management, Prentice Hall, Englewood Cliffs.

Anthony, R.N. (1967), Planning and Control Systems: A Framework for Analysis, Division of Research, Harvard Business School.

Baraldi, S., \& Montaperto, C. (2000), Misurare le performance d'azienda con la Balanced Scorecard, in Sanità \& Management, II Sole 24 Ore, Milan.

Beck Jørgensen, T. (2006). Value Consciousness and Public Management. Organization Theory and Behaviour, 9, 4, 510-36.

Black, S. (1999), Do Better Schools Matter? Parental valuation of elementary education, in Quarterly Journal of Economics, Vol. 114.

Borgonovi, E. (2006), Principi e sistemi aziendali per le amministrazioni pubbliche, Egea, Milan.

Bozeman, B. (2002). Public Value Failure: When Efficient Markets May Not Do. Public Administration Review, 62, 2, 134-151.

Bozman, B. (2007), Public Values and Public Interest. Counterbalancing Economic Individualism, Georgetown University Press.

Bryson, J. M., Crosby, B. C., \& Bloomberg, L. (2014). Public value governance: Moving beyond traditional public administration and the new public management. Public Administration Review, 74(4), 445-456.

Bryson, J., Sancino, A., Benington, J., \& Sørensen, E. (2017). Towards a multi-actor theory of public value co-creation. Public Management Review, 19(5), 640-654.

34 M.H. Moore, The Public Value Scorecard: A Rejoinder and an Alternative to 'Strategic Performance Measurement and Management in Non-Profit Organizations' by Robert Kaplan, Working Paper n.18, Harvard University, Boston, 2003.

${ }^{35}$ Among the public sector organizations that have embraced the philosophy of public value, there is the AngloSaxon BBC (British Broadcasting Corporation). Before making significant changes in a given service, the BBC promulgates a PVT (Public Value Test) finalized to an assessment of the estimated public value and its impact (outcome). The test consists of a Public Value Assessment, carried out by the 'BBC Trust Unit' (in order to determine the likely public value of the proposed change) and of a Market Impact Assessment, which is led by the 'Ofcom' (Office of Communication, the independent authority of regulation of the telecommunications industry in the UK). The overall objective of the Public Value Test is to evaluate quantitatively the potential benefits to the public value expected from the proposed amendments to the broadcasting service and to counteract the damaging effects for the hypothetical market in which the BBC operates. Broadcasting is thus felt a civic art, intrinsically public in ambition and effect. The public value represents in a certain sense the communal glue which some call social capital. 
Caramiello, C. (1965), L'indagine prospettiva nel campo aziendale, Cursi, Pisa.

Chandler A.D.jr. (1962), Strategy and Structure, MIT Press, Cambridge (Mass.).

Chohan, U. W., \& Jacobs, K. (2017). Public value in politics: A legislative budget office approach. International Journal of Public Administration, 40(12), 1063-1073.

Cole, M.I., \& Parston, G. (2006), Unlocking public value: a new model for achieving high performance in public service organizations, John Wiley and Sons, New York.

Colebatch, H.K. (2010). Valuing Public Value: Recognising and Applying. Knowledge About the Governmental Process. The Australian Journal of Public Administration, vol. 69, no. 1, pp. 66-78.

Cowling, M. (2006), Measuring Public Value: The economic theory, The Work Foundation, London.

Denhardt, R.B., \& Denhardt, J.V. (2000), The New Public Service: Serving rather than Steering, in Public Administration Review, Vol. 60, n. 6.

Freeman, R.E. (1984), Strategic Management: A Stakeholder Approach, Pitman, Boston.

Giannessi, E. (1960), Le aziende di produzione originaria, vol. I Le aziende agricole, Cursi, Pisa.

Giovanelli, L. (1995), La comunicazione economica dell'ente locale, Giuffrè, Milan.

Guatri, L., \& Bini, M. (2005), Nuovo trattato sulla valutazione delle aziende, Ube, Milan.

Hills, D., Sullivan, F. (2006), Measuring public value 2: Practical approaches, The Work Foundation, London.

Jackson, P.M. (2001), Public Sector Added Value: Can Bureaucracy Deliver?, in Public Administration, n. $79 / 1$.

Kelly, G., Mulgan, G., \& Muers S. (2002), Creating Public Value: An analytical framework for public service reform, UK Government, Cabinet Office, London.

Kivleniece, I., \& Quelin, B.V. (2012). Creating and capturing value in public-private ties: A private actor's perspective. Academy of Management Review, Vol. 37, No. 2, 272-299.

Latour, B. (2005). Reassembling the Social. An Introduction to Actor Network Theory. Oxford: Oxford University Press.

Meneguzzo, M. (1995), Dal New Public Management alla public governance: il pendolo della ricerca sulla amministrazione pubblica, in Azienda Pubblica, n. 6.

Mintrom, M., \& Luetjens, J. (2017). Creating public value: Tightening connections between policy design and public management. Policy Studies Journal, 45(1), 170-190.

Moore, M.H. (1995), Creating Public Value: Strategic Management in Government, Harvard University Press, Cambridge. 
Moore, M.H. (2003), The Public Value Scorecard: A Rejoinder and an Alternative to 'Strategic Performance Measurement and Management in Non-Profit Organizations' by Robert Kaplan, Working Paper n.18, Harvard University, Boston.

Moore, M.H., \& Khagram, S. (2004), On Creating Public Value. What Business Might Learn from Government about Strategic Management, Working Paper n. 3, Harvard University, Boston, march.

Normann, R. (1977), Management for growth, John Wiley e Sons, Chicester.

O'Flynn, J. (2007). From New Public Management to Public Value: Paradigmatic Change and Managerial Implications. The Australian Journal of Public Administration, vol. 66, no. 3, pp. 353366.

Onesti, T., \& Angiola, N. (ed. by) (2007), La governance dei piccoli comuni, Franco Angeli, Milan.

Onida, P. (2001), Economia d'azienda, Utet, Turin, re-print.

Porter, M.E. (1980), Competitive Strategy: Techniques for Analyzing Industries and Competitors, The Free Press, New York.

Rhodes, R.A.W., \& Wanna, J. (2007). The Limits to Public Value, or Rescuing Responsible Government from the Platonic Guardians. Australian Journal of Public Administration, 66, 4, 406-21.

Romano, M., \& Taliento, M. (2008), La valutazione del capitale umano: stato dell'arte e prospettive di analisi, in AA.VV., La conoscenza nelle relazioni tra aziende, FrancoAngeli, Milan.

Rutgers, M.R. (2008). Sorting out public values? On the contingency of value classifications in public administration. Administrative Theory \& Praxis, Vol. 30, No. 1: 92-113

Schick, A. (2003), The Performing State: Reflection on an Idea Whose Time Has Come but Whose Implementation Has Not, in OECD Journal on Budgeting, Vol. 3, n. 2.

Scott, M., DeLone, W., \& Golden, W. (2016). Measuring eGovernment success: a public value approach. European Journal of Information Systems, 25(3), 187-208.

Stoker, G. (2006), Public Value Management - A New Narrative for Networked Governance?, in The American Review of Public Administration, Vol. 36, n. 1.

Taliento, M. (2016), Public Institutional Environment and Entrepreneurial Value. Theoretical Issues and Efficiency Tests, in New Perspectives on Research, Policy \& Practice in Public Entrepreneurship (pp. 1-36), Emerald Group Publishing Limited.

West, K., \& Davis, P. (2011). What is the public value of government action? Towards a (new) pragmatic approach to values questions in public endeavours. Public Administration, Vol. 89, No. $2(226-241)$.

Williams, I., \& Shearer, H. (2011). Appraising Public Value: Past, Present And Futures. Public Administration, Vol. 89, No. 4, 1367-1384.

Zanda, G., Lacchini, M., \& Onesti, T. (2013), La valutazione delle aziende, Giappichelli, Turin. 